\title{
Three-dimensional evaluation of mid-facial soft tissue changes after expansion using micro- implant-supported maxillary skeletal expander
}

Hieu Nguyen

Ajou University School of Medicine and Graduate School of Medicine Jeong Won Shin

Ajou University School of Medicine and Graduate School of Medicine Hai-Van Giap

Ajou University School of Medicine and Graduate School of Medicine

Ki Beom Kim

Saint Louis University

Hwa Sung Chae

Ajou University School of Medicine and Graduate School of Medicine

\section{Young Ho Kim}

Ajou University School of Medicine and Graduate School of Medicine

Hae Won Choi ( $\nabla$ orthochoi7@gmail.com )

Samsung Medical Center

\section{Research article}

Keywords: Maxillary expansion, micro-implant-supported maxillary skeletal expander (MSE), soft tissue change

Posted Date: July 15th, 2020

DOI: https://doi.org/10.21203/rs.3.rs-18883/v2

License: (c) (1) This work is licensed under a Creative Commons Attribution 4.0 International License. Read Full License 
The authors have withdrawn this preprint from Research Square 